\title{
Development of Microplastic Research in ASEAN
}

\author{
Khodijah $^{1^{*}}$, Sayyidah Nur Habibah ${ }^{2}$ \\ \{khodijah@umrah.ac.id, sayyidahabibah@gmail.com \} \\ ${ }^{1}$ Master of Environmental Science, Raja Ali Haji Tanjungpinang Maritime University, Tanjungpinang, Integrated \\ ${ }^{2}$ Natural Resources Management, Postgraduate Program, Andalas University, Padang, West Sumatra
}

\begin{abstract}
Microplastic research is currently an exciting trend along with global environmental problems. The purpose of this study is to review the development of microplastic research in ASEAN. The researc uses a systematic review method by searching for the keyword "microplastic" and the name of the ASEAN country on the Google Scholar website, Science Direct, and other research paper provider websites. Papers reviewed in 2018 to August 2021 period were then classified based on the components analyzed. The results showed that based on the research location category, the majority of microplastic research was carried out in Vietnam (12/50 articles). The category of research object focused on marine organisms more than terrestrial organisms, the category of microplastic concentration varied because the microplastic sampling method was not standardized, the category of microplastic form dominated by the form of fiber; commonly found in coastal areas. The socio-economic category is not much related to the circular economy. To conclude, microplastic research still has opportunities, especially from a socio-economic perspective.
\end{abstract}

\section{Introduction}

We cannot eliminate the use of plastic in our daily life completely, because plastic is considered to have good economic value although plastic also has a significant contribution to the environmental damage. Environmental damage has attracted a lot of attention from researchers and public in general; since plastic waste is harmful to the environment. Plastics are lightweight, synthetic, or semi-synthetic organic polymers. Plastic are cheap, strong, corrosion-resistant and durable, at the same time no one knows how long it takes for plastic waste to decompose from the marine environment completely. There are many types of plastic waste in the marine environment, such as fishing nets, ropes and plastic bags, occur in the natural environment. An estimated $50 \%$ of plastic products, including tableware, plastic bags and packaging, are intended for single use.

Microplastics are small forms of waste that can be divided into large and small sizes based on their dimension. Large MP (LMP) size ranges from 1 to 5 $\mathrm{mm}$, whereas small MP (SMP) size ranges from $1 \mathrm{~m}$ to $1 \mathrm{~mm}$. Besides, microplastic can be identified from its shape and also based on colors: blue, black, yellow, transparent, white, and red [1].

Primary microplastics are microplastics obtained from cosmetics and health products that contain microbeads or microexfoliates such as polyethylene $(\mathrm{PE})$, polypropylene (PP) and polystyrene (PS) [2]. Secondary microplastics are obtained from plastic degradation through physical, chemical and biological processes [3], for example plastics carried by heavy water currents that cause plastics to be degraded into microplastics [4].

Many kinds of research on microplastics have been carried out in the world, outside of ASEAN countries, one of which is South Korea [5], India [6], to Japan [7]. Another research conducted to proves that microplastics do not only affect marine or aquatic biota but can affect human health through processed foods or other food products [8]; [9]. The research conducted based on the potential exposure to microplastics in living things through the biomagnification process in the food chain [10]. The tiny size of microplastics allows them to be ingested by various living organisms [11]; [12]. The smaller the microplastics size, the level of bioavailability increases so that microplastics can enter microorganisms such as zooplankton [13].

Through this paper hopefully that the current status of microplastic research in ASEAN will be known, and the potential reseaches will be conducted. Expectedly, the variety of microplastic research in ASEAN can further develop and answer the challenges of solving microplastic contamination in ASEAN countries. This paper will review the development of microplastic research in ASEAN and see the potential for future research developments.

*Correspondent Author: khodijah@umrah.ac.id 


\section{Research Method}

The research uses a systematic review method by searching for the keyword "microplastic" and the name of the ASEAN country on the Google Scholar website, Science Direct, and other research paper provider websites. Papers reviewed during 2018 to August 2021 period. The obtained results were then reviewed and classified based on the components of the data to be analyzed. The list of components are listed in Table 1 below.

Tabel 1. The categories of literature review

\begin{tabular}{ll}
\hline No. & Identified categories \\
\hline 1. & Research Location ( Country ) \\
2. & The Object \\
3. & Microplastic concentration \\
4. & Microplastic shape \\
5. & Microplastic type \\
6. & Socio-economic issues \\
\hline
\end{tabular}

The research locations were classified based on the ASEAN countries list, namely Indonesia, Singapore, Malaysia, Thailand, Myanmar, and other countries where microplastics found, such as the Philippines and Vietnam. The research object defined as the specific medium in which microplastics are found or studied, such as in waters, sediments, organisms, and other objects. Meanwhile, the parameters of concentration, shape, type of microplastic, socio-economic impact were analyzed based on the comprehensive data found.

\section{Results and Discussion}

\subsection{Research Site Category}

As the results of literature review from 50 microplastic research papers in ASEAN countries from 2018 to 2021 period, Researcher found that the majority of microplastic research in ASEAN conducted in Vietnam as seen in fig. 1 below.

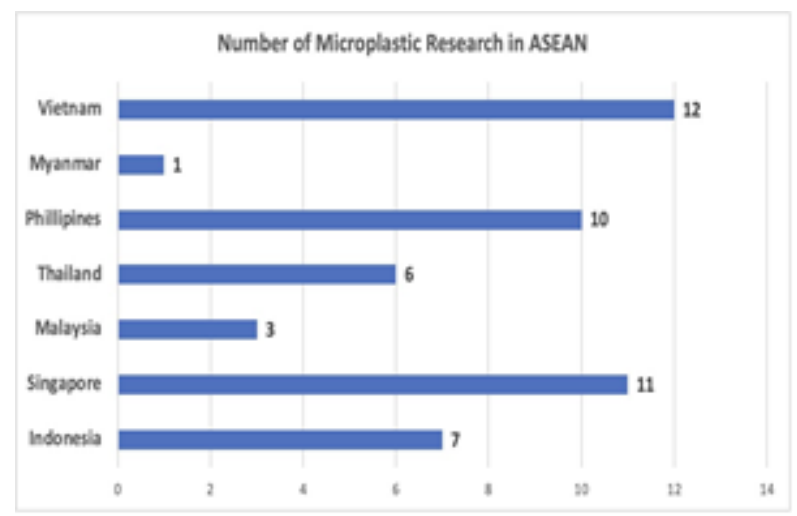

Fig.1. Category of Research Site

In addition to level of the population living on the coast and the economic activities that are primarily carried out in sea and river waters, making research on microplastics in the environment associated with anthropogenic factors becomes more relevant and exciting to do.

Other influences besides population level, high abundance of microplastics come from intense fishing and tourism activities from the middle and downstream [14] this not only happen in river tourism but also happen to the marine tourism sector. Microplastics were significantly more abundant on densely populated beaches than pristine ones, where most microplastics in the form of foam particles and fragments dominated densely populated coastal areas [15]. Concentrations of microplastics in surface waters varied, with the lowest concentrations recorded in bays and highest in rivers where fiber microplastics predominated in most polluted environments [16].

With the existence of activities on the coast or in the middle of sea or river waters, this is a driving factor for the large concentration of microplastic pollution, so that environmental protection efforts are considered to have a positive effect on microplastic pollution [17], [18]. Taken as a whole, highly urbanized coastal environments can accumulate different forms of plastic [19].

\subsection{Research Objects Categories}

Compared to research abroad, the average researcher has started to focus on testing the impact analysis on organisms [20], because this is one of the method to answer whether microplastics are harmful or not. In addition, the method is capable to find out how the level of danger and its mechanism in the organism.

In addition, research on microplastics in soil has not been done much [21]. microplastic in the air [7], and research on microplastics that pay attention at the socioeconomic impact is still lacking [22]. This kind of research has not been done much, considering the sampling test equipment is relatively expensive compared to others [21].

The research conducted by looking at the behavior of fish; by studying the single and interactive effects of microplastics and pyrene, a polycyclic aromatic hydrocarbon, on swimming behavior and fish predator performance [23]. Research conducted in the Philippines, based on the number of marine fish (66.0\%) ingest more MP than freshwater fish [24].

Place the figure as close as possible after the point where it is first referenced in the text. If there is a large number of figures and tables it might be necessary to place some before their text citation.

\subsection{Microplastic Concentration Categories}

The concentration of microplastics at various sampling points has various values [25] ; [26]; [27]; [20] ; [28] ; [29]. The variation of values happened due to the absence of standard procedures for sampling microplastics or standard methods for calculating microplastic concentrations, such as the Standard Method that applies internationally. Between one study and another, different sampling methods are used, so it 
is not possible to compare the concentration values directly without looking at the method used.

For example, the world's microplastic research on sediment samples could use flotation methods [26]). In addition, the observation methods for microplastics are different, some use research from the Marine \& Environmental Research Institute (2015) as standards, some use other research. Similar with the variation of observation method, the chemical testing method where the separation process happend is also still not uniform.

The concentration of microplastics is most commonly found in living organisms such as fish, shrimp and so on [30]; [31].

Apart from finding the highest concentration of microplastics in marine organisms, does not mean that processed food is also contaminated [32] ; [9] ; [33] ; [20].

\subsection{Microplastic Forms Categories}

In terms of the shape of microplastics, it was found that there were more fiber-type plastics than other types of microplastics [34]. This is happend due to microplastic fibers that can come from clothing or textiles through the washing process or other processes [30]. In addition, from previous research on microplastics, it is known that most of them are angular and filamentous with varying colors and translucent [35]. In addition, exposure to microplastics contaminated with marine biota, especially fish, which humans consume as food in their daily lives, will impact on human health, so further investigations into plastic contamination in fish tissues are necessary [33].

The highest level of plastic pollution is in the coastal area, about $85 \%$ of the waste included in the index comes from beach waste [36]. The most abundant plastic waste is plastic wrap in the form of sachets, which is a type of packaging that is not only available in Philippines but also in almost every ASEAN country.

Improper management of solid waste from illegal dumping, for example, encourages the accumulation of microplastics in the environment. However, this still needs to be confirmed with in-depth and focused research on the source of microplastics. According to previous studies, areas that were used as tourism object and managed by the private sector minimalyze the use of single-use plastics and even banned the use of plastic altogether. The policy created by the Management of those tourism object shows the efforts to manage natural resource and better waste management, it makes the category of microplastic pollution is at a low to moderate level [37].

\subsection{Types of Microplastics Category}

The types of microplastics found in various studies in ASEAN are diverse, but not all studies have tested all the types of microplastics. Some of the types found in ASEAN include fiber [38], polietilen [39]; [40], polypropylene [1]; [41], etc. The number of studies related to the types of microplastics has not been widely conducted, but several sampling techniques have been done in several studies such as [42]. The difference in sampling technique could be due to several things, such as methodological and technological constraints in dividing sources and fluxes, characterizing macroplastics/MPs, and identifying socioenvironmental factors that influence [43] and the cost required is relatively expensive compared to just observing using a microscope.

\subsection{Socio-Economic Influence Category}

Humans are very dependant to natural resources that are polluted by microplastic already, so we have to put the social, economic and impacts on the surrounding community into consideration. Coastal communities in particular, put the family's economy on the natural resource environment. Plastic has become a social problem, due to its economic and environmental consequences, affecting human activities and the natural cycles of the planet [44].

Social assessment for plastic waste is quite varied, one of which is the aesthetic value of the environment. Plastic waste also affects the economy of various industries that depend on the coastal environment itself [45]. Plastic waste has an impact on all coastal activities such as marine organism, ecological process; aesthetic, safety and health, decreasing the number of tourism, and others (see Table 2).

Table 2. Social Economic Impact of Microplastics by type of plastic waste [46]

\begin{tabular}{|c|c|c|c|c|c|c|}
\hline & Marine & er sizes, type & and imp & acts* & & \\
\hline & $\begin{array}{l}\text { Marine } \\
\text { litter } \\
\text { size: }\end{array}$ & $\begin{array}{l}\text { Nano } \\
<1 \text { um }\end{array}$ & $\begin{array}{l}\text { Micro } \\
<5 \mathrm{~mm}\end{array}$ & $\begin{array}{l}\text { Meso } \\
<2.5 \mathrm{~cm}\end{array}$ & Macro $<1 \mathrm{~m}$ & Mega $>1 \mathrm{~m}$ \\
\hline 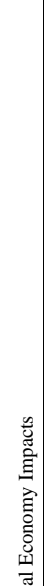 & $\begin{array}{l}\text { Huma } \\
\mathrm{n} \\
\text { health }\end{array}$ & $\begin{array}{l}\text { Risk from } \\
\text { Nanoparti } \\
\text { cles } \\
\text { passing } \\
\text { cell walls. } \\
\text { The } \\
\text { potential } \\
\text { perceived } \\
\text { (subjectiv } \\
\text { e) risk } \\
\text { from } \\
\text { chemical } \\
\text { contamin } \\
\text { ation in } \\
\text { fish and } \\
\text { shellfish } \\
\text { that are } \\
\text { eaten by } \\
\text { human in } \\
\text { the future } \\
\text { and } \\
\text { possible } \\
\text { transfer of } \\
\text { pathogens }\end{array}$ & $\begin{array}{l}\text { Perceiv } \\
\text { risk } \\
\text { contam } \\
\text { shellfis } \\
\text { human } \\
\text { transfer }\end{array}$ & $\begin{array}{l}\text { (subjective) } \\
\text { from chemical } \\
\text { ination in fish and } \\
\text { h that are eaten by } \\
\text { and possible } \\
\text { of pathogens. }\end{array}$ & $\begin{array}{l}\text { Injury on } \\
\text { beaches, } \\
\text { danger to } \\
\text { fishermen, } \\
\text { well-being } \\
\text { loss / mental } \\
\text { health } \\
\text { impacts from } \\
\text { a degraded } \\
\text { environment } \\
\text {. }\end{array}$ & $\begin{array}{l}\text { Loss of } \\
\text { protein fin } \\
\text { (where fish } \\
\text { availability } \\
\text { reduced). } \\
\text { Physical } \\
\text { health risks } \\
\text { of } \\
\text { individuals } \\
\text { becoming } \\
\text { entangled } \\
\text { and mental } \\
\text { health risks } \\
\text { environment } \\
\text { impact : loss } \\
\text { of health } \\
\text { benefit by } \\
\text { avoiding } \\
\text { littered } \\
\text { coastlines }\end{array}$ \\
\hline & $\begin{array}{l}\text { Comm } \\
\text { unities } \\
\text { (e.g. } \\
\text { coastal } \\
\text { fishing } \\
\text { comm } \\
\text { unities } \\
\text { ) }\end{array}$ & $\begin{array}{l}\text { Concern re } \\
\text { health of } \\
\text { community } \\
\text { environmen } \\
\text { Actual } \\
\text { unclear. }\end{array}$ & $\begin{array}{r}\text { rding } \\
\text { the } \\
\text { pacts }\end{array}$ & $\begin{array}{l}\text { Cost of clean- } \\
\text { up, well-being } \\
\text { loss from the } \\
\text { degraded } \\
\text { environment. }\end{array}$ & $\begin{array}{l}\text { Cost of } \\
\text { clean-up, } \\
\text { well-being } \\
\text { loss from the } \\
\text { degraded } \\
\text { environment } \\
; \text { risk to } \\
\text { community , } \\
\text { cohesion / } \\
\text { local identity } \\
/ \text { cultural } \\
\text { values. }\end{array}$ & $\begin{array}{l}\text { Loss of } \\
\text { livelihood, } \\
\text { well-being } \\
\text { loss from the } \\
\text { degraded } \\
\text { environment } \\
\text {; A risk to } \\
\text { community } \\
\text { cohesion / } \\
\text { local identity } \\
\text { / cultural } \\
\text { values }\end{array}$ \\
\hline & $\begin{array}{l}\text { Poor I } \\
\text { povert } \\
\text { y (e.g., } \\
\text { lowest } \\
\text { incom } \\
\text { e } \\
\text { groups } \\
\text { ) }\end{array}$ & $\begin{array}{l}\text { Loss of we } \\
\text { in a } \\
\text { environmen } \\
\text { given "invis } \\
\text { of nano } \\
\text { microplasti } \\
\text { actual per } \\
\text { of well-bei } \\
\text { depends } \\
\text { awareness l }\end{array}$ & $\begin{array}{l}\text { being } \\
\text { lluted } \\
\text { - but } \\
\text { ility" } \\
\text { and } \\
\text { - } \\
\text { ption } \\
\text { loss } \\
\text { on } \\
\text { els }\end{array}$ & $\begin{array}{l}\begin{array}{l}\text { Loss of well- } \\
\text { being }\end{array} \text { in } \\
\text { polluted } \\
\text { environments }\end{array}$ & $\begin{array}{l}\text { Loss of well- } \\
\text { being in } \\
\text { polluted } \\
\text { environment } \\
\text { s }\end{array}$ & $\begin{array}{l}\text { Loss of well- } \\
\text { being, fish } \\
\text { stocks, } \\
\text { tourist } \\
\text { revenue in } \\
\text { polluted } \\
\text { environment } \\
\text { s }\end{array}$ \\
\hline
\end{tabular}


The issue of marine plastic pollution as a global environmental problem requires a cross-disciplinary approach, involving all types of stakeholders. The level of environmental change that occurs as an impact of plastic waste is the first impact which ultimately affects the provision of ecosystem services such as pollution of seafood, salt and the other things that have an impact on human welfare. This includes the loss of jobs, income, and human well-being.

Several factors are driving the occurrence of plastic waste pollution that can be measured. These environmental, social and economic factors identified at the community and household levels. Empirical studies need to be conducted to analyze the effect caused by each factor (Mwanza \& Mbohwa, 2017; Abalansa et al., 2020; UN Environment, 2017; Beaumont et al., 2019). Meanwhile, to measure comprehensive economic insecurity, the Economic Security Index (ESI) analysis can be used, which is by combining data from several surveys [49].

This research is limited to a review of 50 articles and spans from 2018 to 2021, so it is necessary to search for more articles on microplastics in ASEAN. This study recommends conducting multidisciplinary research following the dynamics of environmental problems in the ASEAN region. Various research themes suggested include: 1) The relationship of demographic factors to the abundance of microplastics; 2) Concentration of microplastics in coastal and non-coastal areas; 3) Test analysis of the impact of microplastics on organisms (living in the sea, rivers, land, air); test analysis of the impact of microplastics on soil, air, and on human health; 4) Identification of social and environmental factors that cause pollution due to microplastics; 5) Circular economy and microplastic issues, and others.

\section{Conclusion}

This research concludes:

1. This literature review uses a socio-economic perspective in the theme of microplastic studies, especially research conducted in the ASEAN region, wherein general previous microplastic studies tend to assess the issue of physical and/or chemical effects of polluted objects.

2. There has been a lot of research on microplastics in ASEAN, and it is necessary to continue to develop issues.

3. The research conducted generally has a scope related to the distribution and distribution of microplastics, with the main research location was in Vietnam, followed by the Philippines and Singapore.

4. Research in Indonesia needs to expand the scope or pursue the depth of research that has developed globally, including socio-economic issues related to microplastics.

\section{Acknowledgment}

Thank you to the management of UMRAH environmental science master's program, and the Natural Resources Integrated Management Study
Program Andalas University, for supporting this research

\section{References}

1. P. Lestari, Y. Trihadiningrum, B. A. Wijaya, K. A. Yunus, and M. Firdaus, "Distribution of Microplastics in Surabaya River, Indonesia," Sci. Total Environ., vol. 726, p. 138560, 2020, DOI: 10.1016/j.scitotenv.2020.138560.

2. S. M. Praveena, S. N. M. Shaifuddin, and S. Akizuki, "Exploration of Microplastics From Personal Care and Cosmetic Products and Its Estimated Emissions to Marine Environment: An Evidence From Malaysia," Mar. Pollut. Bull., vol. 136, pp. 135-140, 2018, DOI:

10.1016/j.marpolbul.2018.09.012.

3. S. Summers, T. Henry, and T. Gutierrez, "Agglomeration of Nano- and Microplastic Particles in Seawater by Autochthonous and De Novo-Produced Sources of Exopolymeric Substances," Mar. Pollut. Bull., vol. 130, pp. 258267, 2018, DOI: 10.1016/j.marpolbul.2018.03.039.

4. C. C. Deocaris et al., "Occurrence of Microplastic Fragments In The Pasig River," H2Open J., vol. 2, no. 1, pp. 92-100, 2019, DOI: 10.2166/H2OJ.2019.001.

5. H. Hidayaturrahman and T.-G. Lee, "A Study on Characteristics of Microplastic In Wastewater of South Korea: Identification, Quantification, and Fate of Microplastics During Treatment Process," Mar. Pollut. Bull., vol. 146, pp. 696-702, 2019, DOI: 10.1016/j.marpolbul.2019.06.071.

6. J.-C. Chen et al., "Microplastic Pollution In Wild Commercial Nekton From The South China Sea and Indian Ocean, and Its Implication to Human Health," Mar. Environ. Res., vol. 167, 2021, DOI: 10.1016/j.marenvres.2021.105295.

7. S. Yukioka et al., "Occurrence and Characteristics of Microplastics In Surface Road Dust In Kusatsu (Japan), Da Nang (Vietnam), and Kathmandu (Nepal)," Environ. Pollut., vol. 256, 2020, DOI: 10.1016/j.envpol.2019.113447.

8. K. Senathirajah, S. Attwood, G. Bhagwat, M. Carbery, S. Wilson, and T. Palanisami, "Estimation of the Mass of Microplastics Ingested - A Pivotal First Step Towards Human Health Risk Assessment,” J. Hazard. Mater., vol. 404, 2021, DOI: 10.1016/j.jhazmat.2020.124004.

9. V. T. K. Khuyen, D. V Le, L. H. Anh, A. R. Fischer, and C. Dornack, "Investigation of Microplastic Contamination in Vietnamese Sea Salts Based On Raman and Fourier-Transform Infrared Spectroscopies," EnvironmentAsia, vol. 14, no. 2, pp. 1-13, 2021, DOI: 10.14456/ea.2021.11.

10. P. Kasamesiri and W. Thaimuangpho, "Microplastics Ingestion by Freshwater Fish In The Chi River, Thailand," Int. J. GEOMATE, vol. 18, no. 67 , pp. $114-119,2020$, DOI: 10.21660/2020.67.9110. 
11. A. T. Ta and S. Babel, "Microplastics Pollution With Heavy Metals In The Aquaculture Zone of The Chao Phraya River Estuary, Thailand," Mar. Pollut. Bull., vol. 161, 2020, DOI: 10.1016/j.marpolbul.2020.111747.

12. A. T. Ta and S. Babel, "Microplastic Contamination On The Lower Chao Phraya: Abundance, Characteristic and Interaction with Heavy Metals," Chemosphere, vol. 257, 2020, DOI: 10.1016/j.chemosphere.2020.127234.

13. L. Lahens et al., "Macroplastic and Microplastic Contamination Assessment of A Tropical River (Saigon River, Vietnam) Transversed By A Developing Megacity,” Environ. Pollut., vol. 236, pp. 661-671, 2018, DOI: 10.1016/j.envpol.2018.02.005.

14. A. Pariatamby, F. S. Hamid, M. S. Bhatti, N. Anuar, and N. Anuar, "Status of Microplastic Pollution In Aquatic Ecosystem With A Case Study On Cherating River, Malaysia," J. Eng. Technol. Sci., vol. 52, no. 2, pp. 222-241, 2020, DOI: 10.5614/j.eng.technol.sci.2020.52.2.7.

15. E. Curren and S. C. Y. Leong, "Profiles of Bacterial Assemblages From Microplastics of Tropical Coastal Environments," Sci. Total Environ., vol. 655, pp. 313-320, 2019, DOI: 10.1016/j.scitotenv.2018.11.250.

16. E. Strady et al., "Baseline Assessment of Microplastic Concentrations In Marine and Freshwater Environments of A Developing Southeast Asian Country, Viet Nam," Mar. Pollut. Bull., vol. 162, 2021, DOI: 10.1016/j.marpolbul.2020.111870.

17. R. Bissen and S. Chawchai, "Preliminary Study On the Microplastic Contamination of Beach Sand From Eastern Thailand," 15th Int. Symp. East Asian Resour. Recycl. Technol. EARTH 2019, no. October, 2020.

18. E. Curren, V. S. Kuwahara, T. Yoshida, and S. C. Y. Leong, "Marine Microplastics In the ASEAN Region: A Review of The Current State of Knowledge," Environ. Pollut., vol. 288, 2021, DOI: 10.1016/j.envpol.2021.117776.

19. G. G. M. S. Esquinas, A. P. Mantala, M. G. Atilano, R. P. Apugan, and V. R. K. R. Galarpe, "Physical Characterization of Litter and Microplastic Along The Urban Coast of Cagayan De Oro in Macajalar Bay, Philippines," Mar. Pollut. Bull., vol. 154, 2020, DOI: 10.1016/j.marpolbul.2020.111083.

20. E. Curren, C. P. Leaw, P. T. Lim, and S. C. Y. Leong, "Evidence of Marine Microplastics in Commercially Harvested Seafood," Front. Bioeng. Biotechnol., vol. 8, 2020, DOI: 10.3389/fbioe. 2020.562760 .

21. S. Rostami, M. R. Talaie, A. Talaiekhozani, and M. Sillanpää, "Evaluation of The Available Strategies to Control The Emission of Microplastics Into The Aquatic Environment," Environ. Sci. Pollut. Res., vol. 28 , no. 15 , pp. 18908-18917, 2021, DOI: 10.1007/s11356-021-12888-9.

22. S. Abalansa, B. El Mahrad, G. K. Vondolia, J. Icely, and A. Newton, "The Marine Plastic Litter
Issue: A Social-Economic Analysis," Sustain., vol. 12, no. 20, pp. 1-27, 2020, DOI:

$10.3390 /$ su12208677.

23. O. Guven, L. Bach, P. Munk, K. V Dinh, P. Mariani, and T. G. Nielsen, "Microplastic Does Not Magnify The Acute Effect of PAH Pyrene On Predatory Performance of A Tropical Fish (Lates Calcarifer)," Aquat. Toxicol., vol. 198, pp. 287293, 2018, DOI: 10.1016/j.aquatox.2018.03.011.

24. J. B. P. Cabansag, R. B. Olimberio, and Z. M. T. Villanobos, "Microplastics In Some Fish Species and Their Environs in Eastern Visayas, Philippines," Mar. Pollut. Bull., vol. 167, 2021, DOI: 10.1016/j.marpolbul.2021.112312.

25. R. A. Littman et al., "Coastal Urbanization Influences Human Pathogens and Microdebris Contamination in Seafood," Sci. Total Environ., vol. 736, 2020, DOI:

10.1016/j.scitotenv.2020.139081.

26. N. H. Mohamed Nor and J. P. Obbard, "Microplastics in Singapore's Coastal Mangrove Ecosystems," Mar. Pollut. Bull., vol. 79, no. 1-2, pp. 278-283, 2014, DOI: 10.1016/j.marpolbul.2013.11.025

27. H. Cheng et al., "Toxicities of Microplastic Fibers and Granules On The Development of Zebrafish Embryos and Their Combined Effects with Cadmium," Chemosphere, vol. 269, 2021, DOI: 10.1016/j.chemosphere.2020.128677.

28. N. Seng et al., "Early Evidence of Microplastics On Seagrass and Macroalgae," Mar. Freshw. Res., vol. 71, no. 8, pp. 922-928, 2020, DOI: 10.1071/MF19177.

29. H. Wang et al., "Visible-Light-Driven Removal of Tetracycline Antibiotics and Reclamation of Hydrogen Energy from Natural Water Matrices and Wastewater by Polymeric Carbon Nitride Foam," Water Res., vol. 144, pp. 215-225, 2018, DOI: 10.1016/j.watres.2018.07.025.

30. L. A. Bucol et al., "Microplastics in Marine Sediments and Rabbitfish (Siganus Fuscescens) From Selected Coastal Areas of Negros Oriental, Philippines," Mar. Pollut. Bull., vol. 150, 2020, DOI: 10.1016/j.marpolbul.2019.110685.

31. Andreas et al., "Microplastic Contamination In The Skipjack Tuna (Euthynnus Affinis) Collected From Southern Coast of Java, Indonesia," Chemosphere, vol. 276, 2021, DOI: 10.1016/j.chemosphere.2021.130185.

32. J. D. H. Palermo et al., "Susceptibility of Sardinella Lemuru to Emerging Marine Microplastic Pollution," Glob. J. Environ. Sci. Manag., vol. 6, no. 3, pp. 373-384, 2020, DOI: 10.22034/gjesm.2020.03.07.

33. S. Karbalaei et al., "Abundance and Characteristics of Microplastics in Commercial Marine Fish From Malaysia," Mar. Pollut. Bull., vol. 148, no. May, pp. 5-15, 2019, DOI: 10.1016/j.marpolbul.2019.07.072.

34. Q. A. Tran Nguyen, H. N. Y. Nguyen, E. Strady, Q. T. Nguyen, M. Trinh-Dang, and V. M. Vo, "Characteristics of Microplastics In Shoreline Sediments From A Tropical and Urbanized Beach 
(Da Nang, Vietnam)," Mar. Pollut. Bull., vol. 161, 2020, DOI: 10.1016/j.marpolbul.2020.111768.

35. M. L. Kalnasa, S. M. O. Lantaca, L. C. Boter, G. J. T. Flores, and V. R. K. R. Galarpe, "Occurrence of Surface Sand Microplastic and Litter in Macajalar Bay, Philippines," Mar. Pollut. Bull., vol. 149, 2019, DOI: 10.1016/j.marpolbul.2019.110521.

36. M. K. O. Paler, M. C. T. Malenab, J. R. Maralit, and H. M. Nacorda, "Plastic Waste Occurrence On A Beach Off Southwestern Luzon, Philippines," Mar. Pollut. Bull., vol. 141, pp. 416-419, 2019, DOI: 10.1016/j.marpolbul.2019.02.006.

37. A. D. Syakti et al., "Simultaneous Grading of Microplastic Size Sampling In The Small Islands of Bintan Water, Indonesia," Mar. Pollut. Bull., vol. 137, no. October, pp. 593-600, 2018, DOI: 10.1016/j.marpolbul.2018.11.005.

38. S. Pradit, P. Noppradit, B. P. Goh, K. Sornplang, M. C. Ong, and P. Towatana, "Occurrence of Microplastics and Trace Metals In Fish and Shrimp From Songkhla Lake, Thailand During The COVID-19 Pandemic," Appl. Ecol. Environ. Res., vol. 19, no. 2, pp. 1085-1106, 2021, DOI: $10.15666 /$ aeer/1902_10851106.

39. J. S. Limbago et al., "Occurrence and Polymer Types of Microplastics From Surface Sediments of Molawin Watershed of the Makiling Forest Reserve, Los Baños, Laguna, Philippines," Environ. Nat. Resour. J., vol. 19, no. 1, pp. 57-67, 2021, DOI: 10.32526/ennrj/19/2020114.

40. E. A. Wicaksono, S. Werorilangi, T. S. Galloway, and A. Tahir, "Distribution and Seasonal Variation of Microplastics in Tallo River, Makassar, Eastern Indonesia," Toxics, vol. 9, no. 6, pp. 1-13, 2021, DOI : 10.3390/toxics9060129.

41. A. D. Syakti et al., "Beach Macro-Litter Monitoring and Floating Microplastic In a Coastal Area of Indonesia," Mar. Pollut. Bull., vol. 122, no. 1-2, pp. 217-225, 2017, DOI: 10.1016/j.marpolbul.2017.06.046.

42. B. Cao, S. Wan, Y. Wang, H. Guo, M. Ou, and Q. Zhong, "Highly-Efficient Visible-Light-Driven Photocatalytic H2 Evolution Integrated with Microplastic Degradation Over MXene/ZnxCd1-xS Photocatalyst," J. Colloid Interface Sci., vol. 605, pp. 311-319, 2022, DOI: 10.1016/j.jcis.2021.07.113.

43. V. R. K. R. Galarpe, C. M. B. Jaraula, and M. K. O. Paler, "The Nexus of Macroplastic and Microplastic Research and Plastic Regulation Policies In the Philippines Marine Coastal Environments," Mar. Pollut. Bull., vol. 167, 2021, DOI: 10.1016/j.marpolbul.2021.112343.

44. J. P. Frias, J. A. Ivar do Sul, C. Panti, and A. R. A. Lima, Editorial: Microplastics in the Marine Environment: Sources, Distribution, Biological Effects and Socio-Economic Impacts, vol. 9. 2021.

45. R. Hermawan, A. Damar, and S. Hariyadi, "Dampak Ekonomi Dari Sampah Plastik di Pulau Selayar", Post-graduate Student of Coastal and Marine Resources Management, FPIK-IPB , Bogor Departement of Aquatic Resources Management, vol. 9, no. 1, pp. 327-336, 2017.
46. UN Environment, MARINE LITTER SOCIOECONOMIC STUDY, no. December. 2017.

47. B. G. Mwanza and C. Mbohwa, "Drivers to Sustainable Plastic Solid Waste Recycling: A Review," Procedia Manuf., vol. 8, no. October 2016, pp. 649-656, 2017, DOI: 10.1016/j.promfg.2017.02.083.

48. N. J. Beaumont et al., "Global Ecological, Social and Economic Impacts of Marine Plastic," Mar. Pollut. Bull., vol. 142, no. January, pp. 189-195, 2019, DOI: 10.1016/j.marpolbul.2019.03.022.

49. J. S. Hacker et al., "The Economic Security Index: A New Measure for Research and Policy Analysis," Fed. Reserv. Bank San Fr. Work. Pap. Ser., no. October, pp. 01-56, 2012, DOI: 10.24148/wp201221. 